Journal of Patient-Centered

\title{
Is There Less Opioid Abuse in States Where Marijuana Has Been Decriminalized, Either for Medicinal or Recreational Use? A Clin-IQ
}

\author{
Aaron M. Wendelboe \\ Richard Mathew \\ Tana Chongsuwat \\ Elizabeth Rainwater \\ Mark A. Wendelboe \\ Elizabeth Wickersham MD \\ Ann F. Chou
}

Follow this and additional works at: https://aah.org/jpcrr

Part of the Clinical Epidemiology Commons, Community Health and Preventive Medicine Commons, Criminology and Criminal Justice Commons, Epidemiology Commons, Family Medicine Commons, Patient Safety Commons, Primary Care Commons, and the Substance Abuse and Addiction Commons

\section{Recommended Citation}

Wendelboe AM, Mathew R, Chongsuwat T, Rainwater E, Wendelboe MA, Wickersham E, Chou AF. Is there less opioid abuse in states where marijuana has been decriminalized, either for medicinal or recreational use? A Clin-IQ. J Patient Cent Res Rev. 2019;6:267-73. doi: 10.17294/2330-0698.1704

Published quarterly by Midwest-based health system Advocate Aurora Health and indexed in PubMed Central, the Journal of Patient-Centered Research and Reviews (JPCRR) is an open access, peer-reviewed medical journal focused on disseminating scholarly works devoted to improving patient-centered care practices, health outcomes, and the patient experience. 


\title{
Is There Less Opioid Abuse in States Where Marijuana Has Been Decriminalized, Either for Medicinal or Recreational Use? A Clin-IQ
}

Aaron M. Wendelboe, PhD, ${ }^{1}$ Richard Mathew, MD, ${ }^{2}$ Tana Chongsuwat, MD, ${ }^{2}$ Elizabeth Rainwater, MD, ${ }^{2,3}$ Mark A. Wendelboe, ${ }^{2}$ Elizabeth Wickersham, MD, ${ }^{2}$ Ann F. Chou, PhD, MPH ${ }^{2}$

${ }^{1}$ Department of Biostatistics and Epidemiology, College of Public Health, University of Oklahoma Health Sciences Center, Oklahoma City, OK; ${ }^{2}$ Department of Family and Preventive Medicine, College of Medicine, University of Oklahoma Health Sciences Center, Oklahoma City, OK; ${ }^{3}$ Mid-Del Health Center, Variety Care, Del City, OK

\begin{abstract}
Opioid use, abuse, and associated mortality have reached an epidemic level. In some states, cannabis is being used to treat chronic pain. To examine the hypothesis that medical marijuana legislation may reduce adverse opioid-related outcomes if patients substitute cannabis for opioids for pain management, we conducted a clinical inquiry (Clin-IQ). We searched Ovid MEDLINE, Ovid MEDLINE In-Process, and Embase for studies using the search terms marijuana, cannabis, legal, marijuana smoking, medical marijuana, opioid-related disorders, cannabis use, medical cannabis, legal aspect, and opiate addiction. We included population-based articles published from January 1, 2012, through December 5, 2018, that assessed the relationship between marijuana use and decriminalization and the aforementioned opioid-related outcomes. Ten peer-reviewed studies met the inclusion criteria; 3 cross-sectional studies, 6 ecologic studies (ie, using aggregate data), and 1 retrospective cohort study. Eight studies reported associations between policies decriminalizing marijuana and reduced prescription opioid use, 1 study was inconclusive, and the retrospective cohort study reported an increase in adverse opioid-related outcomes. These results should be interpreted with caution given limitations associated with the studies' design. Results demonstrating association between marijuana decriminalization and opioid-related outcomes are mixed. Longitudinal studies are needed, and further analysis of this policy should continue to be tracked. (J Patient Cent Res Rev. 2019;6:267-273.)
\end{abstract}

Keywords medical marijuana; cannabis; analgesic; opioid; epidemiology; ecologic analysis; decriminalization

\section{Clinical Question}

Is there less opioid abuse in states where marijuana use has been decriminalized, either for medicinal or recreational use?

\section{Brief Answer}

Yes. However, the evidence is mixed. While most reviewed studies showed reductions in rates of opioid overdose and opioid-related hospitalizations, among other outcomes, in states with medical marijuana

Correspondence: Aaron M. Wendelboe, $\mathrm{PhD}$,

801 NE 13th Street, CHB 323, Oklahoma City, OK 73104

(Aaron-Wendelboe@ouhsc.edu) laws, a patient-level report and National Institute on Drug Abuse data indicated an increase in opioid use among cannabis users and higher rates of opioidrelated deaths in these states. Given these mixed results, robust prospective studies are needed to determine the impact of marijuana legislation on opioid use and abuse.

Level of Evidence: B

\section{Literature Search}

Databases: Ovid MEDLINE, Ovid MEDLINE InProcess, PubMed, Embase.

Date range of literature search: January 1, 2012, through December 5, 2018. 
Exclusion criteria: Animal studies, injectable drugs, cannabidiol, non-English language.

Inclusion criteria: Date range within 2012-2018.

Search terms: Marijuana, cannabis, legal, marijuana smoking, medical marijuana, opioid-related disorders, cannabis use, medical cannabis, legal aspect, opiate addiction.

\section{Background}

An estimated 25 million adults in the United States suffer from daily pain, and another 23 million have severe, recurrent pain. Persistent pain causes disability, loss of productivity, lower quality of life, and overall poor health. ${ }^{1}$ There has been a steady increase in the number of opioid prescriptions in the past few decades to manage pain. It is now estimated that the number of annual prescriptions for opioids is approximately equal to the number of adults in the country., ${ }^{2,3}$ Rates of adverse effects of opiate medications, the primary concerns being addiction and overdose, ${ }^{4}$ have concomitantly increased with prescription opioid use. As a result, an average of 115 individuals die daily in the United States from opioid overdose. ${ }^{5}$

Patients who abuse or are dependent on prescription opioids are 40 times more likely to use or abuse heroin compared to those who take opioids as prescribed and have no dependency issues. It is estimated that $4 \%$ of prescription opioid users are expected to become heroin users. ${ }^{6}$ While the hypothesis that marijuana may substitute for opioids exists, there is a concurrent hypothesis that opioid and marijuana use are not mutually exclusive and may be co-occurring. For example, an increase in opioid use/abuse may be associated with an increase in marijuana use. One study reported co-occurring marijuana use to be $13.2 \%$ among nonopioid users, $18.3 \%$ among prescription opioid users, $40.1 \%$ among prescription opioid misusers, 39.9\% among those with prescription opioid use disorder, and 58\% among heroin users. ${ }^{7}$

In response to the opioid crisis, the U.S. Food and Drug Administration (FDA), among other medical and public health organizations, has attempted to identify strategies to curb this epidemic. Marijuana is reported to be an effective method to relieve pain, ${ }^{8,9}$ and authors of a systematic review of the literature concluded that there are data, though limited, suggesting an association between medical cannabis and a reduction in mortality associated with prescription opioid use. ${ }^{10}$ As of 2015 (the cutoff year for data used in the analyses of this study), there were 23 states that had legalized medical marijuana. As of 2016, 31 states had legalized medical marijuana; among these 31,8 states plus Washington, DC, also had legalized recreational marijuana. ${ }^{11}$

Almost two decades after the initiation of individual state-led legalization of medical marijuana, there is mixed evidence regarding the impact of marijuana on opioid-related mortality rates. To that end, the objective of this clinical inquiry (Clin-IQ) project is to explore if a state's decriminalization of marijuana, whether medical or recreational, can attenuate the opioid crisis.

\section{Methods}

We searched Ovid MEDLINE, Ovid MEDLINE InProcess, PubMed, and Embase using the search terms marijuana, cannabis, legal, marijuana smoking, medical marijuana, opioid-related disorders, cannabis use, medical cannabis, legal aspect, and opiate addiction. Studies of animals, injectable drugs, and cannabidiol (commonly referred to as CBD) were excluded. We included articles published from January 1, 2012, through December 5, 2018; however, we limited marijuana-related data to 2015 or prior and opioidrelated data to 2016 or prior to allow a minimum of 1 year to elapse between marijuana decriminalization and subsequent measures of opioid use. Surveillance data for opioid use were not complete for years 2017 and beyond at the time this study was conducted.

\section{Summary of Evidence}

Table 1 summarizes the reviewed literature, which included 1 retrospective cohort study, 3 cross-sectional studies, and 6 ecologic studies using aggregate data.

The retrospective cohort study accessed data from the National Epidemiological Survey on Alcohol and Related Conditions, which assessed associations between cannabis use and 1) prevalent opioid use, 2) incident opioid use, and 3) prescription opioid use disorder. ${ }^{12}$ This data set included a measure of patients' chronic pain. Investigators reported that cannabis use was associated with greater opioid use as defined by these outcomes. ${ }^{12}$ 
Table 1. Summary of Studies Describing the Impact of Medical Marijuana Legislation on Opioid Abuse

\begin{tabular}{|c|c|c|c|c|}
\hline Authors (Year) & Objective & Study Design & Population, Data Collected & Results, Conclusions \\
\hline $\begin{array}{l}\text { Bachuber et al } \\
(2014)^{21}\end{array}$ & $\begin{array}{l}\text { Determine association } \\
\text { between presence of state } \\
\text { medical cannabis laws and } \\
\text { opioid-analgesic-overdose } \\
\text { mortality }\end{array}$ & Ecologic & $\begin{array}{l}\text { Annual state-level death } \\
\text { certificate data from } 1999 \text { to } \\
2010 \text { comparing overdose- } \\
\text { related mortality with time of } \\
\text { marijuana legalization }\end{array}$ & $\begin{array}{l}\text { - Medical marijuana } \\
\text { legalization associated with a } \\
24.8 \% \text { decrease in state-level } \\
\text { opioid-overdose mortality } \\
\text { rates compared to states } \\
\text { without marijuana policies }\end{array}$ \\
\hline $\begin{array}{l}\text { Bradford and } \\
\text { Bradford }(2016)^{16}\end{array}$ & $\begin{array}{l}\text { Investigate how } \\
\text { implementation of state- } \\
\text { level marijuana laws } \\
\text { changes prescribing } \\
\text { patterns }\end{array}$ & Ecologic & $\begin{array}{l}\text { All drugs covered under } \\
\text { Medicare Part D from } 2010 \\
\text { to } 2013\end{array}$ & $\begin{array}{l}\text { - Average } 1826 \text { fewer daily } \\
\text { doses of prescriptions for pain } \\
\text { among states where medical } \\
\text { marijuana is decriminalized } \\
\text { compared to states where } \\
\text { marijuana is illegal }(P<0.01)\end{array}$ \\
\hline $\begin{array}{l}\text { Bradford and } \\
\text { Bradford }(2017)^{17}\end{array}$ & $\begin{array}{l}\text { Investigate association } \\
\text { between state-level } \\
\text { marijuana laws and } \\
\text { prescription drug spending }\end{array}$ & Ecologic & $\begin{array}{l}\text { Average number of opioid } \\
\text { prescriptions filled by } \\
\text { Medicaid beneficiaries } \\
\text { during 2007-2014 }\end{array}$ & $\begin{array}{l}\text { - Approximately } \$ 1.01 \text { billion } \\
\text { savings in } 2014 \text { if every } \\
\text { state had medical marijuana } \\
\text { legislation }\end{array}$ \\
\hline $\begin{array}{l}\text { Corroon et al } \\
(2017)^{14}\end{array}$ & $\begin{array}{l}\text { Survey marijuana users } \\
\text { to determine intentional } \\
\text { substitution of cannabis for } \\
\text { prescription drugs }\end{array}$ & $\begin{array}{l}\text { Cross- } \\
\text { sectional }\end{array}$ & $\begin{array}{l}2774 \text { self-selected marijuana } \\
\text { users largely from U.S., } \\
\text { Canada, Europe }\end{array}$ & $\begin{array}{l}\text { - Cannabis as substitute for } \\
\text { prescription drugs, including } \\
\text { opioids } \\
\text { - No influence by state } \\
\text { marijuana legislation }\end{array}$ \\
\hline $\begin{array}{l}\text { Liang et al } \\
(2018)^{18}\end{array}$ & $\begin{array}{l}\text { Examine if statewide } \\
\text { policies were associated } \\
\text { with a reduction in opioids } \\
\text { received by Medicaid } \\
\text { enrollees }\end{array}$ & Ecologic & $\begin{array}{l}\text { Prescription medication } \\
\text { data for patients enrolled } \\
\text { in fee-for-service Medicaid } \\
\text { programs }\end{array}$ & $\begin{array}{l}\text { - Schedule II opioids (eg, } \\
\text { hydrocodone, oxycodone } \\
\text { [95\% of all prescription } \\
\text { opioids]) were not associated, } \\
\text { but Schedule III opioids (eg, } \\
\text { codeine) were associated with } \\
\text { medical cannabis legalization }\end{array}$ \\
\hline $\begin{array}{l}\text { Olfson et al } \\
(2018)^{12}\end{array}$ & $\begin{array}{l}\text { Determine association } \\
\text { between cannabis use and } \\
\text { change in risk of incident } \\
\text { nonmedical prescription } \\
\text { opioid use }\end{array}$ & $\begin{array}{l}\text { Retrospective } \\
\text { cohort }\end{array}$ & $\begin{array}{l}34,653 \text { participants in waves } \\
1 \text { and } 2 \text { of the National } \\
\text { Epidemiologic Survey } \\
\text { on Alcohol and Related } \\
\text { Conditions }\end{array}$ & $\begin{array}{l}\text { - Increase odds (odds ratio: } \\
2.8 \text { ) of incident nonmedical } \\
\text { opioid among cannabis users } \\
\text { - Similar results when controlling } \\
\text { for self-reported pain }\end{array}$ \\
\hline $\begin{array}{l}\text { Piper et al } \\
(2017)^{15}\end{array}$ & $\begin{array}{l}\text { Study the potential } \\
\text { substitution effect of medical } \\
\text { marijuana for opioids }\end{array}$ & $\begin{array}{l}\text { Cross- } \\
\text { sectional }\end{array}$ & $\begin{array}{l}\text { Online survey }(n=1513) \text { of } \\
\text { members of dispensaries } \\
\text { from Maine, Vermont, } \\
\text { Rhode Island }\end{array}$ & $\begin{array}{l}\text { - Identified that } 76.7 \% \text { of opioid } \\
\text { users substituted marijuana } \\
\text { for opioids to treat chronic pain } \\
\text { - Not designed to estimate impact } \\
\text { of state marijuana legislation }\end{array}$ \\
\hline $\begin{array}{l}\text { Powell et al } \\
(2018)^{19}\end{array}$ & $\begin{array}{l}\text { Assess impact of timing } \\
\text { of medical marijuana } \\
\text { legislation on opioid-related } \\
\text { mortality rates }\end{array}$ & Ecologic & $\begin{array}{l}\text { State-reported opioid-related } \\
\text { mortality rates stratified by } \\
\text { timing of enacting medical } \\
\text { marijuana legislation: }<2010 \text {, } \\
\geq 2010 \text {, or never }\end{array}$ & $\begin{array}{l}- \text { States enacting medical } \\
\text { marijuana legislation reported } \\
\text { deaths per } 100,000 \text { as: } \\
\geq 2010: 3.27 ; \text { never: } 4.05 \\
\text { <2010: } 4.55\end{array}$ \\
\hline Shi $(2017)^{20}$ & $\begin{array}{l}\text { Examine associations } \\
\text { between state medical } \\
\text { marijuana policies and } \\
\text { hospitalizations related to } \\
\text { marijuana and opioids }\end{array}$ & Ecologic & $\begin{array}{l}\text { Annual state-level } \\
\text { hospitalization data from } \\
1997 \text { to } 2014 \text { in } 27 \text { states }\end{array}$ & $\begin{array}{l}\text { - Medical marijuana legalization } \\
\text { was associated with } 9.4 \%- \\
23.0 \% \text { state-level decrease in } \\
\text { opioid-related hospitalizations } \\
\text { compared to states without } \\
\text { marijuana policies }\end{array}$ \\
\hline $\begin{array}{l}\text { Wen et al } \\
(2015)^{13}\end{array}$ & $\begin{array}{l}\text { Examine effect of medical } \\
\text { marijuana legislation on } \\
\text { substance use outcomes in } \\
10 \text { states }\end{array}$ & $\begin{array}{l}\text { Cross- } \\
\text { sectional }\end{array}$ & $\begin{array}{l}\text { Data from NSDUH during } \\
\text { 2004-2012; questions collect } \\
\text { self-reported use of marijuana, } \\
\text { alcohol, prescription pain killers }\end{array}$ & $\begin{array}{l}\text { - No statistically significant } \\
\text { association was observed } \\
\text { between marijuana use and } \\
\text { prescription pain killer use }\end{array}$ \\
\hline
\end{tabular}

NSDUH, National Survey on Drug Use and Health. 
The highest quality of the cross-sectional studies used data collected from the National Survey on Drug Use and Health, which is sponsored by the U.S. Substance Abuse and Mental Health Services Administration. ${ }^{13}$ Selfreported marijuana use was compared to self-reported use of prescription pain killers, from 2004 to 2012 in 10 states. No significant association was observed in either adolescents (age 12-20 years) or adults (age $21+$ years). ${ }^{13}$

The other two cross-sectional studies were based on convenience samples and investigated cannabis use as a substitution for opioids. Corroon et al surveyed marijuana users $(n=2774)$ residing in the United States, Canada, Europe, and "other" via Facebook. ${ }^{14}$ About 60\% of those surveyed self-identified as medical marijuana users. Among the 1248 who responded affirmatively to the question, "Have you ever used cannabis as a substitute for prescription drugs?" substitutions of marijuana were most commonly made for narcotic opioids (35.8\%), anxiolytics/benzodiazepines (13.6\%), and antidepressants (12.7\%). This study found a positive, though not statistically significant, association between substituting marijuana use for opioid use. The study design limited the ability to determine either causation or association. ${ }^{14}$ The study by Piper et al involved medical marijuana users $(n=1513)$ in Maine, Vermont, and Rhode Island. ${ }^{15}$ Of respondents who reported regular use of opioid pain medications $(n=215)$, more than three-quarters $(76.7 \%)$ reported a reduction in opioid use after starting medical marijuana, supporting marijuana use as a substitution for pain medication. This study was conducted only in states where marijuana had been decriminalized; therefore, the impact of legal marijuana use cannot be assessed in the absence of a control group. In addition, multiple authors of this study had previous or hold current employment in cannabis dispensaries, presenting potential conflicts of interest. ${ }^{15}$ Both of these studies had limitations related to selection bias, convenience sampling, and survey design.

A 2016 study by Bradford and Bradford used 20102013 data of all prescription drugs covered under Medicare Part D to investigate the effects of medical marijuana laws on opioid-prescribing patterns. ${ }^{16}$ Data included 9 medical conditions, including pain, that were mentioned in at least 4 states' medical marijuana laws and have at least 1 FDA-approved drug for off-label use. A bivariate analysis comparing "prescriptions filled in a state" and year of marijuana legalization resulted in
1826 fewer daily doses for pain medication filled per physician per year $(\mathrm{P}<0.01)$. To evaluate unobserved characteristics of general differences in prescribing behaviors between physicians in states with and those without marijuana laws, these results were compared with other drug categories for which marijuana has no clinical benefit (blood thinners, antibiotics, etc), and no difference was found. Primary weaknesses of this study included the ecologic study design and sample population consisting of only those $\geq 65$ years of age and enrolled in Medicare Part D. ${ }^{16}$ Bradford and Bradford conducted a subsequent study of similar design using Medicaid data and reported similar findings. ${ }^{17}$

Another study used state-level Medicaid data to assess changes in prescription opioid use over time. ${ }^{18}$ Prescription opioids were stratified into Schedule II (eg, hydrocodone and oxycodone) and Schedule III opioids (eg, codeine). Variables indicating the presence and time of enactment of statewide medical cannabis laws were included in the statistical analysis. The authors reported no association with decreased use of Schedule II opioids but a significant reduction in the use of Schedule III opioids in states that had decriminalized medical marijuana. It should be noted that Schedule II opioids account for approximately $95 \%$ of all prescription opioids; therefore, the overall impact of these reported associations is limited. ${ }^{18}$

Powell et al employed a study design similar to that of Bradford and Bradford but which stratified states into categories based on the timing of adopting medical marijuana laws. ${ }^{19}$ Using 2010 as a cutoff, states enacting medical marijuana legislation before 2010 were considered early adopters and those in 2010 or after were late adopters. States that did not have medical marijuana laws were never adopters. Primary results were mixed; late adopters were found to have the lowest opioid-related mortality rates, followed by never adopters. Early adopter states were found to have the highest opioid-related mortality rates. ${ }^{19}$

In a 2017 ecologic study, Shi applied linear time-series regression analysis using State Inpatient Databases that included information from 27 states that met the inclusion criteria. ${ }^{20}$ This study tested associations between the implementation of medical marijuana policies and rates of hospitalizations from 1997 to 2014 for opioid abuse/ dependence, marijuana abuse/dependence, and opioid- 
related overdose. Results showed an increase in marijuana and opioid-related hospitalizations in all 27 states by $300 \%$, on average, during this time period. However, implementing medical marijuana policies was associated with reduction in hospitalization rates by $23 \%$ for opioid dependence or abuse $(\mathrm{P}=0.008)$ and $13 \%$ for opioid pain reliever overdose $(\mathrm{P}<0.05)$. Additional analyses with lagged effects were conducted, and when assuming a 1-year lag post-medical marijuana policy implementation, there was a $9.4 \%$ reduction in hospitalization rates for opioid dependence or abuse $(\mathrm{P}<0.05)$. However, no difference was observed for marijuana-related hospitalizations. Inconsistencies in data collection and coding practices were limitations of this study. ${ }^{20}$

A 2014 ecologic study by Bachuber et al investigated the association of medical marijuana and opioid-overdose mortality in the United States using vital records. ${ }^{21}$ Applying time-series analysis, the authors compared opioid-overdose mortality rates between all 13 states that had medical marijuana laws effective prior to and during 1999-2010 and those that did not have medical marijuana policies. Results showed a $24.8 \%$ lower mean annual opioid-overdose mortality rate $(95 \% \mathrm{CI}$ : $-37.5 \%$ to $-9.5 \% ; \mathrm{P}=0.003)$ in states with the uptake of marijuana laws compared to states without marijuana laws. This association strengthened over time. The primary weakness of this study is its ecologic/aggregate study design precluding information about medical use among fatal overdose decedents. ${ }^{21}$

To supplement the published literature, we accessed data on the prevalence of opioid prescriptions per 100 population and opioid-related overdose mortality rates per 100,000 population for 2016 from the National Institutes of Health/National Institute on Drug Abuse. ${ }^{22,23}$ Tables 2 and 3 summarize these results for states where medical marijuana had and had not been decriminalized by 2015 , respectively. The crude average prevalence of opioid prescriptions is approximately 20 people per 100

Table 2. Among States Where Medical Marijuana Was Decriminalized by 2015, the State-Specific Years When Marijuana Was Decriminalized for Medical and Recreational Use, Prevalence of Opioid Prescriptions in 2016, and Opioid-Related Death Rate in 2016

\begin{tabular}{|c|c|c|c|c|}
\hline State & $\begin{array}{c}\text { Year } \\
\text { Medical }\end{array}$ & $\begin{array}{c}\text { Year } \\
\text { Recreational }\end{array}$ & $\begin{array}{c}\text { Opioid } \\
\text { Prescriptions per } \\
100 \text { Population }{ }^{22}\end{array}$ & 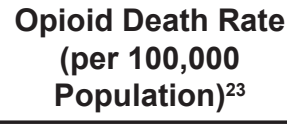 \\
\hline Alaska & 1998 & 2014 & 58.9 & 12.5 \\
\hline Arizona & 2010 & NA & 70.2 & 11.4 \\
\hline California & 1996 & 2016 & 44.8 & 4.9 \\
\hline Colorado & 2000 & 2012 & 59.8 & 9.5 \\
\hline Connecticut & 2012 & NA & 55.9 & 24.5 \\
\hline Delaware & 2011 & NA & 79.2 & 16.9 \\
\hline Hawaii & 2000 & NA & 41.9 & 5.2 \\
\hline Illinois & 2013 & NA & 56.8 & 15.3 \\
\hline Maine & 1999 & 2016 & 66.9 & 25.2 \\
\hline Maryland & 2003 & NA & 58.7 & 30 \\
\hline Massachusetts & 2012 & 2016 & 47.1 & 29.7 \\
\hline Michigan & 2008 & NA & 84.9 & 18.5 \\
\hline Minnesota & 2014 & NA & 46.9 & 7.4 \\
\hline Montana & 2004 & NA & 69.8 & 4.2 \\
\hline Nevada & 2000 & 2016 & 80.7 & 13.3 \\
\hline New Hampshire & 2013 & NA & 64.3 & 35.8 \\
\hline New Jersey & 2009 & NA & 52.6 & 16 \\
\hline New Mexico & 2007 & NA & 65.1 & 17.5 \\
\hline New York & 2014 & NA & 42.7 & 15.1 \\
\hline Oregon & 1998 & 2014 & 76.3 & 7.6 \\
\hline Rhode Island & 2007 & NA & 60.3 & 26.7 \\
\hline Vermont & 2004 & NA & 58.6 & 18.4 \\
\hline Washington & 1998 & 2012 & 64.9 & 30 \\
\hline
\end{tabular}


Table 3. Among States Where Medical Marijuana Was Illegal Through 2015, Prevalence of Opioid Prescriptions and Opioid-Related Death Rate in 2016

\begin{tabular}{|c|c|c|}
\hline State & $\begin{array}{c}\text { Opioid } \\
\text { Prescriptions per } \\
100 \text { Population }{ }^{22}\end{array}$ & $\begin{array}{c}\text { Opioid Death Rate } \\
\text { (per } 100,000 \\
\text { Population) }^{23}\end{array}$ \\
\hline Alabama & 121.0 & 7.5 \\
\hline Arkansas & 114.6 & 5.9 \\
\hline Florida & 66.6 & 14.4 \\
\hline Georgia & 77.8 & 8.8 \\
\hline Idaho & 77.6 & 7.4 \\
\hline Indiana & 83.9 & 12.6 \\
\hline lowa & 64.0 & 6.2 \\
\hline Kansas & 76.9 & 5.1 \\
\hline Kentucky & 97.2 & 23.6 \\
\hline Louisiana & 98.1 & 7.7 \\
\hline Mississippi & 105.6 & 6.2 \\
\hline Missouri & 80.4 & 15.9 \\
\hline Nebraska & 62.8 & 2.4 \\
\hline North Carolina & 82.5 & 15.4 \\
\hline North Dakota & 47.8 & 7.6 \\
\hline Ohio & 75.3 & 32.9 \\
\hline Oklahoma & 97.9 & 11.6 \\
\hline Pennsylvania & 69.5 & 18.5 \\
\hline South Carolina & 89.4 & 13.1 \\
\hline South Dakota & 54.8 & 5.0 \\
\hline Tennessee & 107.5 & 18.1 \\
\hline Texas & 57.6 & 4.9 \\
\hline Utah & 70.4 & 16.4 \\
\hline Virginia & 63.4 & 13.5 \\
\hline West Virginia & 96.0 & 43.4 \\
\hline Wisconsin & 62.2 & 15.8 \\
\hline Wyoming & 71.1 & 8.7 \\
\hline
\end{tabular}

higher among states where medical marijuana is illegal (mean: 81.1 of 100; range: $47.8-121.0$ ) than states where medical marijuana has been decriminalized (mean: 61.2 of 100; range: 41.9-84.9). ${ }^{22}$ No adjustment was made for time between policy change and measurement of opioid prescription prevalence or opioid-related overdose mortality rate. In contrast, the average death rate of opioid-related overdoses is 3.79 people per 100,000 higher among states where medical marijuana has been decriminalized (mean: 17.2 of 100,000; range: 4.2-35.8) compared to states where marijuana was illegal through 2015 (mean: 13.4 of 100,000; range: $2.4-43.4){ }^{23}$ These findings stem from a crude analysis using ecologic/aggregate study design; therefore, overall impact and interpretation is limited.
Given that state-level data are ecologic and the person-level data are drawn from convenience samples, these data serve to generate hypotheses rather than establishing causal relationships. This field is rapidly changing because of policy implications. For example, clinical practice may have changed as a result of the U.S. Centers for Disease Control and Prevention guidance on the prescribing practices of opioids. ${ }^{24}$ Using the Strength of Recommendation Taxonomy (SORT) criteria by Ebell et al, the level of evidence to support the hypothesis that opioid use decreases among states where marijuana use has been decriminalized is level B ("recommendation based on inconsistent or limited-quality patient-oriented evidence"). ${ }^{25}$ Additional epidemiologic studies at the patient level (especially cohort studies) are needed to better understand the impact decriminalizing marijuana use has on opioid abuse.

\section{Conclusions}

With the ongoing opioid epidemic, it is critical to scrutinize medical marijuana as a substitute for pain medications in terms of its analgesic properties and potential harm. Based on this literature review, there is mixed evidence regarding the impact of marijuana legislation and prescription opioid-related outcomes. Eight studies provided evidence of reductions in the rate of opioid overdose, opioid-related hospitalizations, number of narcotic pain prescriptions written, and patient-reported substitution of marijuana for opiates, in states with medical marijuana laws. However, the one patient-level study reported an actual increase in opioid use among cannabis users. Data from the National Institute on Drug Abuse also indicated states with medical marijuana laws had higher rates of opioid-related overdose deaths. In addition, the variability across study design, measures of opioid abuse, and measures of marijuana use in the reviewed studies contributes to the challenges in identifying a consistent pattern in the results.

Given these mixed results, more robust studies in which patients are followed prospectively to measure the association between cannabis use and opioidrelated outcomes are sorely needed to determine the impact of marijuana legislation on opioid use and abuse. 


\section{Patient-Friendly Recap}

- The opioid addiction epidemic has pushed health care providers to seek out new means of managing chronic pain.

- In states where legal to do so, marijuana is likely to be increasingly prescribed in lieu of opioids when attempting to treat patients with chronic pain.

- After reviewing the available literature to date, the authors concluded there is less overall opioid abuse in states that have legalized marijuana; however, some contradictory data indicating opioid-related deaths may increase in these same states suggests further research is necessary.

\section{Author Contributions}

Study design: A. Wendelboe, Mathew, Chongsuwat, Rainwater, Wickersham, Chou. Data acquisition or analysis: A. Wendelboe, Mathew, Chongsuwat, M. Wendelboe, Chou. Manuscript drafting: A. Wendelboe, Mathew, Chongsuwat, M. Wendelboe, Chou. Critical revision: A. Wendelboe, Rainwater, Wickersham, Chou.

\section{Conflicts of Interest}

None.

\section{References}

1. Meldrum ML. The ongoing opioid prescription epidemic: historical context. Am J Public Health. 2016;106:1365-6. CrossRef

2. Centers for Disease Control and Prevention. Opioid overdose. U.S. opioid prescribing rate maps. Last reviewed 2018 Oct 3. https://www.cdc.gov/drugoverdose/maps/rxrate-maps.html. Accessed April 17, 2019.

3. Marcus H. Prescribing opioids safely. Posted 2017 Sep 16. https://www.msms.org/About-MSMS/News-Media/ prescribing-opioids-safely. Accessed April 17, 2019.

4. Califf RM, Woodcock J, Ostroff S. A proactive response to prescription opioid abuse. N Engl J Med. 2016;374:1480-5. CrossRef

5. Centers for Disease Control and Prevention. Opioid overdose. Understanding the epidemic. Last reviewed 2018 Dec 19. https://www.cdc.gov/drugoverdose/epidemic/index.html. Accessed January 9, 2019.

6. Lucyk SN, Nelson LS. Toxicosurveillance in the US opioid epidemic. Int J Drug Policy. 2017;46:168-71. CrossRef

7. Winkelman TN, Chang VW, Binswanger IA. Health, polysubstance use, and criminal justice involvement among adults with varying levels of opioid use. JAMA Netw Open. 2018;1(3):e180558. CrossRef

8. Maher DP, Carr DB, Hill K, et al. Cannabis for the treatment of chronic pain in the era of an opioid epidemic: a symposiumbased review of sociomedical science. Pain Med. 2017 Jul 13 [Epub ahead of print]. $\underline{\text { CrossRef }}$
9. Whiting PF, Wolff RF, Deshpande S, et al. Cannabinoids for medical use: a systematic review and meta-analysis. JAMA. 2015;313:2456-73. CrossRef

10. Vyas MB, LeBaron VT, Gilson AM. The use of cannabis in response to the opioid crisis: a review of the literature. Nurs Outlook. 2018;66:56-65. CrossRef

11. Haffajee RL, MacCoun RJ, Mello MM. Behind schedule reconciling federal and state marijuana policy. $N$ Engl J Med. 2018;379:501-4. CrossRef

12. Olfson M, Wall MM, Liu SM, Blanco C. Cannabis use and risk of prescription opioid use disorder in the United States. Am J Psychiatry. 2018;175:47-53. CrossRef

13. Wen H, Hockenberry JM, Cummings JR. The effect of medical marijuana laws on adolescent and adult use of marijuana, alcohol, and other substances. $J$ Health Econ. 2015;42:64-80. CrossRef

14. Corroon JM Jr, Mischley LK, Sexton M. Cannabis as a substitute for prescription drugs - a cross-sectional study. J Pain Res. 2017;10:989-98. CrossRef

15. Piper BJ, DeKeuster RM, Beals ML, et al. Substitution of medical cannabis for pharmaceutical agents for pain, anxiety, and sleep. J Psychopharmacol. 2017;31:569-75. CrossRef

16. Bradford AC, Bradford WD. Medical marijuana laws reduce prescription medication use in Medicare Part D. Health Aff (Millwood). 2016;35:1230-6. CrossRef

17. Bradford AC, Bradford WD. Medical marijuana laws may be associated with a decline in the number of prescriptions for Medicaid enrollees. Health Aff (Millwood). 2017;36:945-51. CrossRef

18. Liang D, Bao Y, Wallace M, Grant I, Shi Y. Medical cannabis legalization and opioid prescriptions: evidence on US Medicaid enrollees during 1993-2014. Addiction. 2018;113:2060-70. CrossRef

19. Powell D, Pacula RL, Jacobson M. Do medical marijuana laws reduce addictions and deaths related to pain killers? $J$ Health Econ. 2018;58:29-42. 당sㄹef

20. Shi Y. Medical marijuana policies and hospitalizations related to marijuana and opioid pain reliever. Drug Alcohol Depend. 2017; 173:144-50. CrossRef

21. Bachhuber MA, Saloner B, Cunningham CO, Barry CL. Medical cannabis laws and opioid analgesic overdose mortality in the United States, 1999-2010. JAMA Intern Med. 2014;174:1668-73. CrossRef

22. Centers for Disease Control and Prevention. Annual Surveillance Report of Drug-Related Risks and Outcome United States, 2017. Surveillance Special Report 1, published 2017 Aug 31. Available at: https://www.cdc.gov/drugoverdose/ pdf/pubs/2017-cdc-drug-surveillance-report.pdf. Accessed July 23, 2018.

23. National Institute on Drug Abuse. Opioid summaries by state. Updated 2017 Dec 31. https://www.drugabuse.gov/drugs-abuse/ opioids/opioid-summaries-by-state. Accessed July 23, 2018.

24. Dowell D, Haegerich TM, Chou R. CDC guideline for prescribing opioids for chronic pain - United States, 2016. MMWR Recomm Rep. 2016;65(1):1-49. CrossRef

25. Ebell MH, Siwek J, Weiss BD, et al. Strength of recommendation taxonomy (SORT): a patient-centered approach to grading evidence in the medical literature. $J \mathrm{Am}$ Board Fam Pract. 2004;17:59-67. CrossRef

(C) 2019 Aurora Health Care, Inc. 